\title{
DIFFERENCES IN EXPLOSIVE POWER BETWEEN BASKETBALL PLAYERS OF DIFFERENT AGE
}

\author{
Nikola Aksović, Dragana Berić \\ University of Niš, Faculty of Sport and Physical Education, Serbia
}

\begin{abstract}
The aim of this research is to determine the differences in explosive power between basketball players of different age. This research was conducted on the sample of 34 basketball players, 17 of them wereat the age of 11 and 17 of them were at the age of 14 ( \pm 0.5 years). They are all members of basketball club „Ras”, Novi Pazar. Six different kinds of test were used to estimate their explosive power: long jump, triple jump, medicine balls throw while lying, medicine ball sit-up throw, sprinting in $20 \mathrm{~m}$ from the low start position, sprinting in $30 \mathrm{~m}$ from the high start position. For identifying the significant differences in main values of two groups of players was used t-test. The statistics significance in differences was analyzed at the level $(\mathrm{p}<0.05)$. The results show that there are statistically significant differences between basketball players of different age in all observed variables and that they go in favor of players aged 14.
\end{abstract}

Key words: BASKETBAL PLAYERS / JUMPS / THROWING / SPRINTING

\section{INTRODUCTION}

Basketball is anaerobic-aerobic sport with interchangeable phases of high load, where for being successful is necessarily technical, tactical and physical preparation. The explosive power in basketball is manifested through different jumps, starting acceleration, sudden changes in the direction of movement, slowing down (deceleration), sudden stopping and in passing the ball to each other (Khlifa, et al., 2010). Knowing the explosive power of players of different age is the direct relationship with the effects of training and it makes easier the coach to choose the methods, the process of planning and program for the players. Mostly, the explosive power depends on the number of motor units, the genetic conditionality is $80 \%$. It is defined as the ability of sportsman, in the shortest period of time the highest possible force is produced (Zatsiorsky \& Kraemer, 2009).

The researches of this type are numerous in the world and at our place (Maffiuletti, Cometti, Amiridis, Martin, Pousson, \& Chatard, 2000; Khlifa et al., 2010; Santos \& Janeira, 2012; Kocić, Berić, Radovanović, \& Simović, 2012). Even though the inborn coefficient plays an important role, the development of explosive power can be done through good and organized trainings which should be conducted as well planned, rational and organized. Many authors show that the explosive power is the characteristic of professional basketball players (Latin, Berg, \& Baechle, 1994; Hoffman, Tenenbaum, Maresh, \& Kraemer, 1996; Ziv \& Lidor, 2009). This belief was shown to be shared by the National Basketball Association strength and conditioning coaches who reported an extensive to improve explosive-power performance in elite-level professional basketball players (Hoffman et al., 1996; Simenz, Dugan, \& Ebben, 2005). Furthermore, the published papers only addressed young basketball players selectively using drop jumps as training exercises (Meyer, Brown, Krilowicz, \& Kushmerick, 1986; Matavulj, Kukolj, Ugarkovic, Tihanyi, \& Jaric, 2001). Also, application plyometric training with young athletes has been recommended for explosive strength development (Kolb, 2003; Chu, Faigenbaum, \& Falkel, 2006). Only one basket game consists of $46 \pm 12$ jumps per player (McInnes, Carlson, \& McKenna, 1995), and this shows

36 Correspondence to: Nikola Aksović, University of Niš, Faculty of Sport and Physical Education, , Čarnojevića 10a, 18000 Niš, Serbia: e-mail: kokir87np@gmail.com 
us the importance of explosive power in jumps. Due to the fact that today's basketball demands durable players with developed motor skills, the explosive power is one of the most important factors for achieving the best sports results in sport such as basketball results (McBride, Triplett-McBride, Davie, \& Newton, 2002; Carlock, et al., 2004). The researches also show the positive correlation of jumps and throws at basketball players of different age (Santos \& Janeira, 2011). In the past, the basketball coaches were convinced that the speed of sprinting is conditioned with genetics and it could not be improved with training, but in the last few years, the basketball coaches recognized the importance of explosive power such as sprinting (Moreno, 1994). Today, genetics is considered as one of the factors which help to determine the maximal speed of potential sportsman.

The assumption of research is that there will be differences in explosive power between basketball players of different age. So, it is expected that there will be differences in the explosive power, in favor of basketball players aged 14 years, and the key factors that contribute to the confirmation of hypotheses are biological maturity, anthropometric dimension, the level participants preparedness and age players. Therefore, the aim of this study is to determine the differences in explosive power between basketball players of different age.

\section{METHOD}

\section{Participans}

The sample of players for this research is 34 , and all of them are members of basketball club "Ras” from Novi Pazar. They were divided into two groups. In the first group, there were 17 of players, (age $14 \pm$ 0.5 years, body height $172.7 \pm 8.78 \mathrm{~cm}$, body weight $60.7 \pm 11.3 \mathrm{~kg}$, BMI $\left.20.57 \pm 2.15 \mathrm{~kg} / \mathrm{m}^{2}\right)$, and the second group consisted also of 17 players (age $11 \pm 0.5$ years, body height $153.2 \pm 5.83 \mathrm{~cm}$, body weight 46.9 $\pm 8.3 \mathrm{~kg}$, BMI $20.04 \pm 2.09 \mathrm{~kg} / \mathrm{m}^{2}$ ). All of the exami- nees accepted to take part in this research. They were all healthy, without any chronic diseases or injuries which could influence the results of testing.

\section{Samples of variables}

In order to estimate the explosive power of players different tests were used (Kurelić, Momirović, Stojanović, Štrum, Radojević, \& Viskić-Štalec, 1975; Gredelj, Metikoš, Hošek, \& Momirović, 1975): long jump (MSDM), triple jump (MTRS), medicine balls throw while lying (MBML), medicine ball sit-up throw (MBMS), sprinting in $20 \mathrm{~m}$ from low start position (M20N), sprinting in $30 \mathrm{~m}$ from high start position (M30V).

\section{Data Analysis}

All the data were processed in Statistical Package for Social Sciences SPSS (v19.0, SPSS Inc., Chicago, IL, USA). Data processing was used basic descriptive parameters: minimum value (Min.), maximum value (Max.), arithmetic mean (Mean), Standard deviation (St. Dev.), rate asymmetry (Skewness and Kurtosis). To determine a statistically significant differences between the groups for each variable, t-test was used. Because of the small sample of participants, Cohen's d effect size (ES) was used to compare the explosive power between basketball players age 14 and 11 years. ES magnitudes were classified according to the scale $(\geq 0.2=$ small; $0.2<\mathrm{ES}<0.8=$ moderate $\leq 0.8=$ large $)$ described by Cohen (1998). Probability level for statistical significance was set at $\mathrm{p}<0.05$.

\section{RESULTS}

In tables 1 and 2 are showed new descriptive parameters for basketball players at the age of 14 and 11. By examining the tables and comparing the results of Standard Deviation (St. Dev.), with maximal range (Max.) and minimal (Min.), one can conclude the normal sensibility of chosen tests

Table 1. The basic statistic parameters of basketball players, age 14

\begin{tabular}{llllcccc}
\hline \multicolumn{1}{c}{ Variables } & N & Min. & Max. & Mean & St. Dev. & Skewness & Kurtosis \\
\hline MSDM (cm) & 17 & 143.0 & 215.0 & 176.4 & 17.42 & .161 & .428 \\
MTRS (cm) & 17 & 339.0 & 654.0 & 542.2 & 74.77 & -1.264 & 2.314 \\
MBML (cm) & 17 & 432.0 & 762.0 & 634.8 & 102.47 & -.775 & -.257 \\
MBMS (cm) & 17 & 398.0 & 634.0 & 524.3 & 81.23 & -.265 & -1.287 \\
M20N (s) & 17 & 3.25 & 4.05 & 3.69 & .2352 & .001 & -.762 \\
M30V (s) & 17 & 4.22 & 5.50 & 4.78 & .4571 & .296 & -1.650 \\
\hline
\end{tabular}


The value of Skewness shows that there is no significant deviations of normal distribution consider that the values do not go over \pm 1.00 . The kurtosis values in all tests are below 2.75 , which indicates platykurtic distribution. Only the values of kurtosis
(2.883) which are given in running variable at 30 $\mathrm{m}$ from standing start, basketball players of age 11, show the increased asymmetry of distribution and its lengthiness to higher values, what shows us the reduced test discrimination.

Table 2. The basic statistic parameters of basketball players, age 11

\begin{tabular}{lccccccc}
\hline \multicolumn{1}{c}{ Variables } & N & Min. & Max. & Mean & St. Dev. & Skewness & Kurtosis \\
\hline MSDM $(\mathbf{c m})$ & 17 & 125.0 & 172.0 & 145.0 & 12.74 & .126 & -.020 \\
MTRS $(\mathbf{c m})$ & 17 & 403.0 & 523.0 & 474.4 & 32.03 & -.580 & .189 \\
MBML $(\mathbf{c m})$ & 17 & 310.0 & 497.0 & 417.2 & 43.84 & -.624 & 1.317 \\
MBMS (cm) & 17 & 290.0 & 510.0 & 396.4 & 59.54 & -.295 & -.322 \\
M20N $(\mathbf{s})$ & 17 & 3.73 & 5.18 & 4.17 & .4120 & 1.832 & 2.883 \\
M30V (s) & 17 & 4.89 & 6.80 & 5.61 & .5046 & .675 & .448 \\
\hline
\end{tabular}

In table 3 are shown the results of the t-test, which shows the explosive power of basketball players, age 14 and 11. The given results show the significant differences between the players of different age in all kind of tests which were used for evaluating the explosive power, and that were long jump (MSDM
.000), triple jump (MTRS .002), medicine balls throw while lying (MBML .000), medicine ball sit-up throw (MBMS .000), sprinting in $20 \mathrm{~m}$ from low start position (M20N .000), sprinting in $30 \mathrm{~m}$ from high start position (M30V .000).

Table 3. The differences in explosive power between the players of age 14 and 11

\begin{tabular}{ccccccc}
\hline Variables & Group & Mean & St. Dev. & ES & t & p \\
\hline \multirow{2}{*}{ MSDM (cm) } & 14 age & 176.4 & 17.42 & & & \\
& 11 age & 145.0 & 12.74 & 2.12 & 5.999 & $\mathbf{. 0 0 0}$ \\
MTRS (cm) & 14 age & 542.2 & 74.77 & & & \\
& 11 age & 474.4 & 32.03 & 1.21 & 3.435 & $\mathbf{. 0 0 2}$ \\
MBML (cm) & 14 age & 634.8 & 102.47 & & & \\
& 11 age & 417.2 & 43.84 & 3.45 & 8.049 & $\mathbf{. 0 0 0}$ \\
MBMS (cm) & 14 age & 524.3 & 81.23 & & & \\
& 11 age & 396.4 & 59.54 & 1.85 & 5.237 & $\mathbf{. 0 0 0}$ \\
M20N (s) & 14 age & 3.69 & .2352 & & & \\
& 11 age & 4.17 & .4120 & 1.45 & -4.125 & $\mathbf{. 0 0 0}$ \\
M30V (s) & 14 age & 4.78 & .4571 & & & \\
& 11 age & 5.61 & .5046 & 1.77 & -5.018 & $\mathbf{. 0 0 0}$ \\
\hline
\end{tabular}

Very large ES differences between basketball players of different age were observed in all kind of tests MSDM (ES = 2.12), MTRS (ES = 1.21), MBML (ES $=3.45), \mathrm{MBMS}(\mathrm{ES}=1.85), \mathrm{M} 20 \mathrm{~N}(\mathrm{ES}=1.45)$, and $\mathrm{M} 20 \mathrm{~V}(\mathrm{ES}=1.77)$.

\section{DISCUSSION}

The primary purpose of the current study study was to determine the differences in explosive power between the basketball players aged 14 and 11 years. After the data evaluation, it is concluded that there are significant differences between the players of different age in all observed variables, and all of them are in favor of older players, age 14 . The given results are expected, and the reason for that can be the age, their anthropometric dimension (body height, body weight), genetic predisposition, the level parcitipans preparedness, and playing position in team. Köklü, Alemdaroğlu, Ünver Koçak, \& Findikoğlu (2011) discovered the differences in the explosive power of the 
lower limbs in basketball players of the First and the Second Turkish League, and discovered significant differences in the performance, as well as in the playing position.

Perhaps the most sensitive factor of given results is age, since the training of children and young basketball players mustn't be based on the principles that training for adults is based on. It has to be in compliance with their biological, chronological, psychological and physical growth. The researches show that the basketball players, who belong to the group of young pioneers (10-12 years old), develop their explosive power through different ways of moving, the body's weight itself makes resistance through the game and the explosive power such as sprint is improved through short sprints. At basketball pioneers (13-14 years) the one can influence the most on the development of explosive power, and can be used minimal external loads (Pavlović, 2007).

It should also be noted that in the implementation of training to develop explosive power players, we should bear in mind the anthropometric dimensions (body height and body weight) for anthropometric dimensions of his influence exercised in applying the most exercises with reversible contraction. Athletes with specific morphological constitution should not apply high-intensity exercise and scale (Čoh, 2004).

When it is about the explosive power of upper extremities, the next tests were used throwing a medicine ball, and the results showed differences in favor of basketball players aged 14 years, as it is expected. Research suggests that the use of medicinal balls can affect the development of explosive power of upper extremities (Gambetta, 1986) because the three most common types of inclusion that can be seen in basketball are passing from the chest, above his head and baseball defense. It is also known that the growth and maturation have a positive effect on the improvement of explosive power at men. The explosive power during this period is positively associated with chronological age, constitution and the variation in body weight (Bosco, 1994). From this point of view, after analyzing the groups, it can be said that differences were confirmed in all tests for the evaluation of explosive power where the importance of growth, development and maturation factors of men are confirmed.

Explosive power is manifested in basketball through various types of jumps, starting acceleration and quick changes of direction, deceleration, passing the ball, and is therefore the very topical field of research (Casartelli, Müller, \& Maffiuletti, 2010; Castagna, Ganzetti, Ditroilo, Giovannelli, Rocchetti, \& Manzi, 2013; Battaglia, Paoli, Bellafiore, Bianco, \& Palma, 2014). Several studies show a significant difference in the jumps between players with different levels of performance (Hoare, 2000; Delextrat \& Cohen, 2008; Ostojić, Stojanović, \& Ahmetović, 2010) indicating that the best players in the team tend to jump more than others. The research suggests that a player (if he plays the entire game) runs 6000-7000 meters carries out up to 40 different jumps, makes about 280 changes of direction, catching 120 balls, passing 80. Researchers say that for each player for the game half plays 16-17 jumps, which would through recalculating of the whole game turned out to be about 35 (Narazaki, Berg, Stergiou, \& Chen, 2009). For this reason (Stojanovic, Ostojic, Calleja-González, Milosevic, \& Mikic, 2012) suggest that coaches should spend more time on developing the explosive power to elite basketball players because it has a big impact on the competitive success in basketball. The conclusion has been made that it is necessary to use more strength training in sports practice, and that this type of training is an effective tool for basketball coaches, very innovative in terms of strength development, contributing to the efficiency of training time (Ademović, Kocić, Berić, \& Daskaloski, 2015).

Besides that it was established a positive correlation between explosive power and running in short distances (Berthoin, Dupont, Mary, \& Gerbeaux, 2001), which is considered to be a significant predictor of success in basketball (Latin et al., 1994). Zhang (2013) in addition to investigating explosive power, also investigated the speed of running over short distances, endurance in strength, and noted the positive influence of the explosive force in individual leg strength and endurance in general. It is necessary to know that type of short endurance training was specially designed for young basketball players, causing an increase in explosive strength, which is very important for the results of the game without any extra burden on the development of skeletal muscles (Ademović et al., 2015). As such, it is a common routine training which needs devotion of certain period of time in the development of explosive power, especially during the preparatory period (Pauletto, 1994). 


\section{CONCLUSION}

This research was conducted on a sample of 34 basketball players, at the age of 11 and 14 ( \pm 0.5 years) with the aim to determine the differences in explosive power between the basketball players of different age. By applying t-test, we have got the results which show us that there is a significant difference between

\section{REFERENCES}

1. Ademović, I.H., Kocic, M.R., Berić, D.I., \& Daskaloski, B.S. (2015). Explosive leg strength of elite basketball players. Facta Universitatis, Series: Physical Education and Sport, 13(2), 253-261.

2. Battaglia, G., Paoli, A., Bellafiore, M., Bianco, A., \& Palma, A. (2014). Influence of a sport-specific training background on vertical jumping and throwing performance in young female basketball and volleyball players. Journal Sports Medicine and Physical Fitness, 54, 581-587.

3. Berthoin, S., Dupont, G., Mary, P., \& Gerbeaux, M. (2001). Predicting sprint kinematic parameters from anaerobic field tests in physical education students. The Journal of Strength \& Conditioning Research, 15(1), 75-80.

4. Bosco, C. (1994). La Valoracio'n de la Fuerza con el Test de Bosco. Barcelona: Editorial Paidotribo.

5. Carlock, J.M., Smith, S.L., Hartman, M.J., Morris, R.T., Ciroslan, D.A., Pierce, K.C., \& Stone, M.H. (2004). The relationship between vertical jump power estimates and weightlifting ability: a fieldtest approach. The Journal of Strength \& Conditioning Research, 18(3), 534-539.

6. Casartelli, N., Müller, R., \& Maffiuletti, N. A. (2010). Validity and reliability of the myotest accelerometric system for the assessment of vertical jump height. The Journal of Strength \& Conditioning Research, 24(11), 3186-3193.

7. Castagna, C., Ganzetti, M., Ditroilo, M., Giovannelli, M., Rocchetti, A., \& Manzi, V. (2013). Concurrent validity of vertical jump performance assessment systems. The Journal of Strength \& Conditioning Research, 27(3), 761-768.

8. Chu, D.A., Faigenbaum, A.D., \& Falkel, J.E. (2006). Progressive plyometrics for kids. Monterey, CA: Healthy Learning. the basketball players of different age in all observed variables, and all of them are in favor of older players, age 14 . The given results provide the important information for coaches, which helps in players selection and it helps in making a proper plan and program of work for players of different age and points out to the further researches in the field of explosive power between players of different age.

9. Cohen, J. (1988). Statistical Power Analysis for the Behavioral Sciences. New Jersey: Lawrence Erlbaum Associates.

10. Čoh, M. (2004). Metodika i dijagnostika razvoja skočnosti u kondicijskoj pripremi sportaša [Methods and diagnostic development vertical jump in the physical conditioning of athletes. In Croatian]. Proccedings of International Scientific Conference of Physical Preparation of Athletes (pp. 104-118). Zagreb: Kineziološki fakultet sveučilišta u Zagrebu i Udruga kondicijskih trenera Hrvatske.

11. Delextrat, A., \& Cohen, D. (2008). Physiological testing of basketball players: toward a standard evaluation of anaerobic fitness. The Journal of Strength \& Conditioning Research, 22(4), 1066-1072.

12. Gambetta, V. (1986). Practical considerations for utilizing plyometrics-Roundtable. NSCA Journal, 14-22.

13. Gredelj, M., Metikoš, D., Hošek, A., \& Momirović, K. (1975). Model hijerarhijske strukture motoričkih sposobnosti. Rezultati dobiveni primjenom jednog neoklasičnog postupka za procjenu latentnih dimenzija [Model of hierarchical structure of motor abilities. The results obtained using a neo-classical procedure for the evaluation of the latent dimensions. In Croatian-Serbian]. Kineziologija, 5(1-2), 7-82.

14. Hoare, D.G. (2000). Predicting success in junior elite basketball players-the contribution of anthropometic and physiological attributes. Journal of Science and Medicine in Sport, 3(4), 391-405.

15. Hoffman, J.R., Tenenbaum, G., Maresh, C.M., \& Kraemer, W.J. (1996). Relationship Between Athletic Performance Tests and Playing Time in 
Elite College Basketball Players. The Journal of Strength \& Conditioning Research, 10(2), 67-71.

16. Khlifa, R., Aouadi, R., Hermassi, S., Chelly, M. S., Jlid, M.C., Hbacha, H., \& Castagna, C. (2010). Effects of a plyometric training program with and without added load on jumping ability in basketball players. The Journal of Strength \& Conditioning Research, 24(11), 2955-2961.

17. Kocić, M., Berić, D., Radovanović, D., \& Simović, S. (2012). Differences in mobility, situational, motor and functional abilities of basketball players at different levels of competition. Facta universitatis, Series: Physical Education and Sport, 10(1), 23-32.

18. Köklü, Y., Alemdaroğlu U., Ünver Koçak, F., Erol A.E., \& Findikoğlu, G. (2011). Comparison of Chosen Physical Fitness Characteristics of Turkish Professional Basketball Players by Division and Playing Position. Journal of Human Kinetics (Section III- Sports Training), 30, 99-106.

19. Kolb, J.J. (2003). Get Fit Now for High School Basketball: The Complete Guide for Ultimate Performance. Hatherleigh Press.

20. Kurelić, N., Momirović, K., Stojanović, M., Štrum, J., Radojević, Đ. \& Viskić-Štalec, N. (1975). Struktura i razvoj morfoloških i motoričkih dimenzija omladine [The structure and development of morphological and motor dimensions of the youth. In Serbaina-Croatian]. Belgrade: The Institute for Scientific Research of the Faculty of Physical Education in Belgrade.

21. Latin, R.W., Berg, K., \& Baechle, T. (1994). Physical and Performance Characteristics of NCAA Division I Male Basketball players. The Journal of Strength \& Conditioning Research, 8(4), 214-218.

22. Maffiuletti, N.A., Cometti, G., Amiridis, I.G., Martin, A., Pousson, M., \& Chatard, J.C. (2000). The Effects of Electromyo-stimulation Training and Basketball Practice on Muscle Strength and Jumping Ability. International Journal of Sports Medicine, 21(6), 437-443.

23. Matavulj, D., Kukolj, M., Ugarkovic, D., Tihanyi, J., \& Jaric, S. (2001). Effects of plyometric training on jumping performance in junior basketball players. Journal of Sports Medicine and Physical Fitness, 41(2), 159-164.

24. McBride, J.M., Triplett-McBride, T., Davie, A., \& Newton, R.U. (2002). The effect of heavy-vs. light- load jump squats on the development of strength, power, and speed. The Journal of Strength \& Conditioning Research, 16(1), 75-82.

25. McInnes, S.E., Carlson, J.S., Jones, C.J., \& McKenna, M.J. (1995). The physiological load imposed on basketball players during competition. Journal of Sports Sciences, 13(5), 387-397.

26. Meyer, R.A., Brown, T.R., Krilowicz, B.L., \& Kushmerick, M.J. (1986). Phosphagen and intracellular $\mathrm{pH}$ changes during contraction of creatine-depleted rat muscle. American Journal of Physiology-Cell Physiology, 250(2), C264-C274.

27. Moreno, E. (1994). Defining and developing quickness in basketball, Part I. Strength Condition, 16, 53-54.

28. Narazaki, K., Berg, K., Stergiou, N., \& Chen, B. (2009). Physiological demands of competitive basketball. Scandinavian Journal of Medicine \& Science in Sports, 19(3), 425-432.

29. Ostojić, S.M., Stojanović, M., \& Ahmetović, Z. (2010). Vertical jump as a tool in assessment of muscular power and anaerobic performance. Medicinski pregled, 63(5-6), 371-375.

30. Pauletto, B. (1994). Strength training for basketball. Human Kinetics.

31. Pavlović, D. (2007). Specifičnosti razvoja snage i brzine kod mlađih košarkaša [Specifics of the development of power and speed in young basketball players. In Croatian]. Proccedings of International Scientific Conference of Physical Preparation of Athletes, (pp.160-163). Zagreb: Kineziološki fakultet sveučilišta u Zagrebu i Udruga kondicijskih trenera Hrvatske.

32. Santos, E.J., \& Janeira, M.A. (2011). The effects of plyometric training followed by detraining and reduced training periods on explosive strength in adolescent male basketball players. The Journal of Strength \& Conditioning Research, 25(2), 441-452.

33. Santos, E.J., \& Janeira, M.A. (2012). The effects of resistance training on explosive strength indicators in adolescent basketball players. The Journal of Strength \& Conditioning Research, 26(10), 2641-2647.

34. Simenz, C.J., Dugan, C.A., \& Ebben, W.P. (2005). Strength and conditioning practices of National Basketball Association strength and conditioning coaches. The Journal of Strength \& Conditioning Research, 19(3), 495-504. 
35. Stojanovic, M., Ostojic, S., Calleja-González, J., Milosevic, Z., \& Mikic, M. (2012). Correlation between explosive strenght, aerobic power and repeated sprint ability in elite basketball players. Journal of Sports Medicine and Physical Fitness, 52(4), 375-381.

36. Zatsiorsky, V., \& Kraemer, W. (2009). Nauka $i$ praksa $u$ treningu snage [Science and practice in strength training. In Serbian]. Beograd: Data status.
37. Zhang, X. (2013). Research of Jumping Ability and Explosive Power Based on PlyometricTraining. Lecture Notes in Electrical Engineering, 206, 427-433.

38. Ziv, G., \& Lidor, R. (2010). Vertical jump in female and male basketball players-review of observational and experimental studies. Journal of Science and Medicine in Sport, 13(3), 332-339.

\title{
UNTERSCHIEDE IN DER EXPLOSIVEN KRAFT BEI BASKETBALLSPIELERN UNTERSCHIEDLICHEN ALTERS
}

\begin{abstract}
Zusammenfassung
Die Untersuchung wurde an einem Muster von 34 Basketballspielern des Basketballclubs „Ras“ aus Novi Pazar durchgeführt. Davon waren 17 Spieler im Alter von 11 Jahren und 17 Spieler im Alter von 14 Jahren (+/- 0.5 Jahre). Ziel der Untersuchung war es, die Unterschiede zwischen der explosiven Kraft bei Basketballspielern unterschiedlichen Alters festzustellen. Für die Einschätzung der explosiven Kraft wurden sechs Tests angewendet: Weitsprung aus dem Stand, Dreisprung aus dem Stand, Medizinballwurf aus liegender Position, Medizinballwurf aus Sitzposition mit gespreizten Beinen, 20 Meter-Sprint aus niedrigem Start, 30 Meter-Sprint aus hohem Start. Für die Festlegung der Bedeutung der Unterschiede der Mittelwerte der beiden Gruppen wurde der t-test angewendet. Die statistische Bedeutung der Unterschiede wurde auf der Ebene $(\mathrm{p}<0.05)$ analysiert. Die Ergebnisse weisen darauf hin, dass statistisch bedeutende Unterschiede zwischen Baskettballspielern unterschiedlichen Alters in allen betrachteten Variablen zu Gunsten der Basketballspieler im Alter von 14 Jahren vorhanden sind.
\end{abstract}

Schlüsselwörter: BASKETBALLSPIELER / SPRÜNGE / WÜRFE / SPRINT

Received: 13.10 .2016$.

Accepted: 10.04.2017. 


\title{
РАЗЛИКЕ У ЕКСПЛОЗИВНОЈ СНАЗИ ИЗМЕБУ КОШАРКАША РАЗЛИЧИТОГ УЗРАСТА
}

\author{
Никола Аксовић, Драгана Берић \\ Универзитет у Нишу, Факултет спорта и физичког васпитања
}

\begin{abstract}
Сажетак
Истраживање је спроведено на узорку од 34 кошаркаша, 17 кошаркаша узраста 11 година и 17 кошаркаша узраста 14 година ( \pm 0.5 година) Кошаркашког клуба „Рас“ из Новог Пазара, са циљем утврђивања разлика у експлозивној снази између кошаркаша различитог узраста. За процену експлозивне снаге примењено је шест тестова: скок удаљ из места, троскок из места, бацање медицинке из лежања на леђима, бацање медицинке из седа разножног, спринт на $20 \mathrm{~m}$ из ниског старта, спринт на $30 \mathrm{~m}$ из високог старта. За утврђивање значајности разлика средњих вредности две групе кошаркаша примењен је t-тест. Статистичка значајност разлика анализирана је на нивоу $(\mathrm{p}<0.05)$. Добијени резултати указују да постоје статистички значајне разлике између кошаркаша различитог узраста у свим посматраним варијаблама у корист кошаркаша узраста од 14 година.
\end{abstract}

Кључне речи: КОШАРКАШИ / СКОКОВИ / БАЦАҢА / СПРИНТ

\section{УвОД}

Кошарка је анаеробно-аеробни спорт са наизменичним фазама високих оптерећења где је за успех неопходна техничка, тактичка и физичка припрема. У кошарци, експлозивна снага се манифестује кроз разне варијанте скокова, стартног убрзања, изненадне промене смера кретања, успорења, наглог заустављања и додавања. Познавање експлозивне снаге код кошаркаша различитог узраста у директној је вези са ефектима тренинга што тренеру олакшава избор метода, процес планирања и програмирања. Експлозивна снага првенствено зависи од броја активираних моторних јединица, генетска условљеност је $80 \%$, и дефинише се као способност спортисте да за најкраће могуће време произведе највећу могућу силу (Zatsiorsky \& Kraemer, 2009).

Истраживања експлозивне снаге код кошаркаша различитог узраста су бројна у свету и код нас (Maffiuletti, Cometti, Amiridis, Martin, Pousson, \& Chatard, 2000; Khlifa, Aouadi, Hermassi, Chelly, Jlid, Hbacha, \& Castagna, 2010; Santos \& Janeira, 2012; Čvorović, Kocić, \& Berić, 2011; Kocić, Berić,
Radovanović, \& Simović, 2012). И поред високог коефицијента урођености, развој експлозивне снаге могуће је реализовати кроз добро организоване тренинге које би требало спроводити плански, рационално и организовано. Многи аутори указују да је експлозивна снага значајна карактеристика професионалних кошаркаша (Latin, Berg, \& Baechle, 1994; Hoffman, Tenenbaum, Maresh, \& Kraemer, 1996; Ziv \& Lidor 2009). У великом броју радова, који се односе на експлозивну снагу младих кошаркаша, може се уочити да се селективно користе дубински скокови у тренажном вежбањy (Meyer, Brown, Krilowicz, \& Kushmerick, 1986; Matavulj, Kukolj, Ugarkovic, Tihanyi, \& Jaric, 2001). Такође, примена плиометријског тренинга се препоручује за развој експлозивне снаге младих спортиста, а уједно и кошаркаша (Kolb, 2003; Chu, Faigenbaum, \& Falkel, 2006). Само један кошарка-

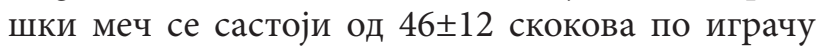
(Mclennes, Carlson, \& McKenna, 1995), што указује на значај експлозивне снаге типа скокова. У спортовима као што је кошарка експлозивна снага је

36 Кореспонденција са: Никола Аксовић, Универзитет у Нишу, Факултет спорта и физичког васпитања, Чарнојевића 10A, 18000 Ниш; e-mail: kokir87np@gmail.com 
један од најзначајних фактора за постизање врхунских спортских резултата (McBride, Triplett-McBride, Davie, \& Newton, 2002; Carlock, Smith, Hartman, Morris, Ciroslan, Pierce, \& Stone, 2004), јер данашња кошарка захтева издржљиве играче са добро развијеним моторичким способностима. Истраживања указују и на позитивну корелацију скокова и бацања код кошаркаша различитог узраста (Santos \& Janeira, 2011). Последњих година кошаркашки тренери су препознали значај експлозивне снаге типа спринта, јер су у прошлости били убеђени да је брзина трчања условљена генетиком, и да се не може побољшати тренингом (Moreno, 1994). Данас се генетика сматра једним од фактора за утврђивање максималног брзинског потенцијала спортисте.

Претпоставка истраживања је да ће постојати разлике у експлозивној снази између кошаркаша различитог узраста. Значи, очекује се да ће постојати разлике у експлозивној снази, у корист кошаркаша узраста 14 година, а кључни фактори који доприносе потврђивању хипотезе су биолошка зрелост, антропометријске карактеристике, ниво припремљености и узраст кошаркаша. Дакле, циљ истраживања је био утврђивање разлика у експлозивној снази између кошаркаша различитог узраста.

\section{МЕТОД}

\section{Узорак испитаника}

Узорак испитаника је чинило 34 кошаркаша Кошаркашког клуба „Рас“ из Новог Пазара, подељени у два субузорка. Први субзорак је чинило 17 кошаркаша (узраста $14 \pm 0.5$ година, телесне висине $172.7 \pm 8.78 \mathrm{~cm}$, телесне тежине $60.7 \pm 11.3$ $\mathrm{kg}$, BMI $20.57 \pm 2.15 \mathrm{~kg} / \mathrm{m}^{2}$ ), а други 17 кошаркаша (узраста $11 \pm 0.5$ година, телесне висине $153.2 \pm$ $5.83 \mathrm{~cm}$, телесне тежине $46.9 \pm 8.3 \mathrm{~kg}$, BMI 20.04 $\pm 2.09 \mathrm{~kg} / \mathrm{m}^{2}$ ). Сви испитаници су добровољно дали сагласност за учешће у истраживању. Били су здрави, без икаквих хроничних обољења или повреда локомоторног апарата које би утицале на резултате тестирања.

\section{Узорак мерних инструмената и варијабли}

За процену експлозивне снаге примењени су следећи тестови: скок удаљ из места (MSDM), троскок из места (MTRS), бацање медицинке из лежања на леђима (MBML), бацање медицинке из седа разножног (MBMS), спринт на 20 из ниског старта (M20N), спринт на 30 из високог старта (M30V).

\section{Обрада података}

Сви подаци су обрађени статистичким пакетом Statictical Package for Social Sciencess (v19.0, SPSS Inc., Chicago, IL, USA). За обраду података израчунати су основни дескриптивни параметри: аритметичка средина (Mean), минимална вредност (Min), максимална вредност (Max), стандардна девијација (St. Dev.), мере асиметричности (Skewness i Kurtosis).

За утврђивање значајности разлика средњих вредности између две групе кошаркаша примењен је t-тест. 3ठог малог узорка испитаника израчунат је Cohen's d effect size (ES), за поређење експлозивне снаге између кошаркаша узраста 14 и 11. година. ES вредности су класификоване $(\geq 0.2$ = мали; $0.2<\mathrm{ES}<0.8=$ умерен; $\leq 0.8=$ велики) (Cohen, 1998). Статистичка значајност разлика је анализирана на нивоу $\mathrm{p}<0.05$.

\section{РЕЗУЛТАТИ}

У табели 1 и 2 приказани су основни дескриптивни параметри за кошаркаше узраста 14 и 11 година.

Табела 1. Основни статистички параметри кошаркаша узраста 14 година

\begin{tabular}{lccccccc}
\hline \multicolumn{1}{c}{ Варијабле } & N & Min & Мax & АC & CД & Skewness & Kurtosis \\
\hline MSDM (cm) & 17 & 143.0 & 215.0 & 176.4 & 17.42 & .161 & .428 \\
MTRS (cm) & 17 & 339.0 & 654.0 & 542.2 & 74.77 & -1.264 & 2.314 \\
MBML (cm) & 17 & 432.0 & 762.0 & 634.8 & 102.47 & -.775 & -.257 \\
MBMS (cm) & 17 & 398.0 & 634.0 & 524.3 & 81.23 & -.265 & -1.287 \\
M20N (s) & 17 & 3.25 & 4.05 & 3.69 & .2352 & .001 & -.762 \\
M30V (s) & 17 & 4.22 & 5.50 & 4.78 & .4571 & .296 & -1.650 \\
\hline
\end{tabular}


Прегледом табела може се констатовати да се упоређивањем резултата стандардне девијације (СД), са распоном максималних (Мах) и минималних (Min) резултата, може закључити нормална осетљивост изабраних тестова. Вредност скјуниса показују да нема значајних одступања од нормалне диструбуције, с обзиром да вредности не прелазе 1.00 , док се резултати куртозиса крећу испод нормалне вредности дистрибуције
2.75, што дистрибуцију чини платикуртичном или расплинутом. Једино вредности куртозиca (2.883) код варијабле трчање на $30 \mathrm{~m}$ из високог старта, код кошаркаша узраста 11 година показују увећану асиметричност дистрибуције и њену развученост ка већим вредностима, односно указује на смањену дискриминативност теста, на повећану концентрацију резултата око средње вредности.

Табела 2. Основни статистички параметри кошаркаша узраста 11 година

\begin{tabular}{lccccccc}
\hline \multicolumn{1}{c}{ Варијабле } & N & Min & Max & AC & CД & Skewness & Kurtosis \\
\hline MSDM (cm) & 17 & 125.0 & 172.0 & 145.0 & 12.74 & .126 & -.020 \\
MTRS (cm) & 17 & 403.0 & 523.0 & 474.4 & 32.03 & -.580 & .189 \\
MBML (cm) & 17 & 310.0 & 497.0 & 417.2 & 43.84 & -.624 & 1.317 \\
MBMS (cm) & 17 & 290.0 & 510.0 & 396.4 & 59.54 & -.295 & -.322 \\
M20N (s) & 17 & 3.73 & 5.18 & 4.17 & .4120 & 1.832 & 2.883 \\
M30V (s) & 17 & 4.89 & 6.80 & 5.61 & .5046 & .675 & .448 \\
\hline
\end{tabular}

У табели 3 су приказани резултати t-теста експлозивне снаге кошаркаша, узраста 14 и 11 година. Добијени резултати приказују статистички значајне разлике између кошаркаша различитог узраста у свим тестовима за процену експлозивне снаге: скок удаљ из места (MSDM .000), троскок из места (MTRS .002), бацање медицинке из лежања на леђима (MBML .000), бацање медицинке из седа разножног (MBMS .000), спринт на 20 m из ниског старта (M20N .000), спринт на 30 m из високог старта (M30V .000).

Табела 3. Разлике у експлозивној снази између кошаркаша узраста 14 и 11 . година

\begin{tabular}{lcccccc}
\hline \multicolumn{1}{c}{ Варијабле } & Групе & АC & СД & ES & t & p \\
\hline MSDM (cm) & 14 год & 176.4 & 17.42 & & & \\
& 11 год & 145.0 & 12.74 & 2.12 & 5.999 & $\mathbf{. 0 0 0}$ \\
MTRS (cm) & 14 год & 542.2 & 74.77 & & & \\
& 11 год & 474.4 & 32.03 & 1.21 & 3.435 & $\mathbf{. 0 0 2}$ \\
MBML (cm) & 14 год & 634.8 & 102.47 & & & \\
& 11 год & 417.2 & 43.84 & 3.45 & 8.049 & $\mathbf{. 0 0 0}$ \\
MBMS (cm) & 14 год & 524.3 & 81.23 & & & \\
& 11 год & 396.4 & 59.54 & 1.85 & 5.237 & $\mathbf{. 0 0 0}$ \\
M20N (s) & 14 год & 3.69 & .2352 & & & \\
& 11 год & 4.17 & .4120 & 1.45 & -4.125 & $\mathbf{. 0 0 0}$ \\
M30V (s) & 14 год & 4.78 & .4571 & & & \\
& 11 год & 5.61 & .5046 & 1.77 & -5.018 & $\mathbf{. 0 0 0}$ \\
\hline
\end{tabular}

Велике ES разлике између кошаркаша различитог узраста су утврђене у свим тестовима: MSDM (ES = 2.12), MTRS (ES = 1.21), MBML (ES $=3.45), \mathrm{MBMS}(\mathrm{ES}=1.85), \mathrm{M} 20 \mathrm{~N}(\mathrm{ES}=1.45)$, and $\mathrm{M} 20 \mathrm{~V}(\mathrm{ES}=1.77)$.

\section{ДИСКУСИЈА}

Ово истраживање је једно у низу спроведених истраживања са циљем анализе и обраде ек- сплозивне снаге кошаркаша различитог узраста. Након обраде података, закључено је да постоје статистички значајне разлике између кошаркаша различитог узраста у свим посматраним варијаблама у корист кошаркаша узраста 14. година. Добијени резултати су очекивани, а као један од разлога може бити узраст испитаника, антропометријске димензије, ниво припремљености, локомоторни апарат је боље развијен код старијих кошаркаша. Коклу и сарадници (Köklü, Alemdaroğlu, Ünver Koçak, Erol, \& Findikoğlu 2011) 
су открили разлике у екслозивној снази доњих екстремитета кошаркаша I и II турске лиге, и указали на значајне разлике у перформансама, као и на основу њихове играчке позиције у тиму.

Можда и најосетљивији фактор добијених резултата јесте узраст, јер тренинг деце и младих кошаркаша не сме се заснивати на принципима тренинга одраслих, већ мора бити усклађен са њиховим биолошким, хронолошким, психолошким и физичким развојем. Истраживања указуjу да кошаркаши који припадају категорији млађих пионира (10-12 година), тренинг за развој експлозивне снаге спроводи се кроз различите природне облике кретања, кроз игру, отпор чини властита тежина тела, док се експлозивна снага типа спринта развија кратким спринтовима. Код кошаркаша пионира (13-14 година) највише се може деловати на развој експлозивне снаге, а могу се користити минимална спољна оптерећења. У узрасту 15-16 година (кадети) поступно се повећавају могућности коришћења спољних оптерећења (Pavlović, 2007).

У примени тренинга за развој експлозивне снаге, приликом одабира одговарајућег оптерећења, треба имати у виду и антропометријске димензије спортисте, телесну висину и телесну масу, јер антропометријске карактеристике свој утицај остварују највише приликом примене вежби са реверзибилном контракцијом. Чох (С̌oh, 2004) наводи да спортисти са специфичном морфолошком конституцијом не би требало да примењују плиометријске вежбе великог обима и интезитета.

Што се тиче експлозивне снаге горњих екстремитета примењени су тестови бацања медицинке, и добијени резултати су приказали разлике у корист кошаркаша узраста 14 година, што је и очекивано. Истраживања указују да се употребом медицинских лопти може утицати на развој експлозивне снаге горњих екстремитета (Gambetta, 1986), јер три најчешће врсте додавања која се могу видети у кошарци су додавање са груди, изнад главе и бејзбол додавање. Такође је познато да раст и сазревање имају позитиван ефекат на побољшање експлозивне снаге код мушкараца. Експлозивна снага у том периоду је позитивно повезана са хронолошким узрастом, конституцијом и варијацијом у телесној маси (Bosco, 1994). Са ове тачке гледишта, након анализирања група може се рећи да су утврђене разлике у свим те- стовима за процену експлозивне снаге, где је потврђен значај раста, развоја и фактора сазревања мушкараца.

Експлозивна снага се у кошарци манифестује кроз разне врста скокова, стартног убрзања и брзе промене правца кретања, успорења, додавања, и због тога је веома актуелно поље истраживања (Casartelli, Müller, \& Maffiuletti, 2010; Castagna, Ganzetti, Ditroilo, Giovannelli, Rocchetti, \& Manzi, 2013; Battaglia, Paoli, Bellafiore, Bianco, \& Palma, 2014). Више студија приказују значајне разлике у скоковима између кошаркаша са различитим нивоима успешности (Hoare, 2000; Delextrat \& Cohen, 2008; Ostojić, Stojanović, \& Ahmetović, 2010) указујући да најбољи играчи у тима имају тенденцију да скоче више од других. Истраживања показују да играч (ако игра целу утакмицу) претрчи 6000-7000 метара, изведе до 40 различитих скокова, око 280 промена праваца, 120 хватања лопте, 80 додавања, 16 шутева на кош. Истраживачи наводе да за једно полувреме играч изведе од 16-17 скокова, што би прерачунавањем на целу утакмицу испало око 35 (Narazaki, Berg, Stergiou, \& Chen, 2009). Због тог разлога (Stojanovic, Ostojic, Calleja-González, Milosevic, \& Mikic, 2012) сматрају да тренери треба да посвете више времена развоју експлозивне снаге код елитних кошаркаша, јер има велики утицај на такмичарску успешност у кошарци. Закључак је да је неопходно посветити више пажње тренингу експлозивне снаге, јер је ефективно средство кошаркашким тренерима веома иновативан у смислу развоја снаге, који доприноси ефикасности тренинга (Ademović, Kocić, Berić, \& Daskaloski, 2015).

Осим тога утврђена је позитивна корелација експлозивне снаге и трчања на кратким дистанцама (Berthoin, Dupont, Mary, \& Gerbeaux, 2001), која се сматра значајним предиктором за успех у кошарци (Latin et al., 1994). Чанг (Zhang, 2013) је испитивао експлозивну снагу, брзину трчања на кратким дистанцама, издржљивост у снази, и указао на позитиван утицај експлозивне снаге на снагу доњих екстремитета и генерално на издржљивост. Зато је неопходно знати да је овакав тип кратког тренинга издржљивости специјално дизајниран за младе кошаркаше, и да доприноси повећању експлозивне снаге, која је веома значајан фактор за постизање врхунских резултата (Ademović et al., 2015). Као такав, он је заједнички 
рутински тренинг коме треба посветити одређени временски период у развоју експлозивне снаге, нарочито током припремног периода (Pauletto, 1994).

\section{ЗАКЉУЧАК}

Истраживање је спроведено на узорку 34 кошаркаша узраста 11 и 14 година ( \pm 0.5 година), са циљем да се утврде разлике у експлозивној снази

\section{ЛИТЕРАТУРА}

1. Ademović, I.H., Kocic, M.R., Berić, D.I., \& Daskaloski, B.S. (2015). Explosive leg strength of elite basketball players. Facta Universitatis, Series: Physical Education and Sport, 13(2), 253-261.

2. Battaglia, G., Paoli, A., Bellafiore, M., Bianco, A., \& Palma, A. (2014). Influence of a sport-specific training background on vertical jumping and throwing performance in young female basketball and volleyball players. Journal Sports Medicine and Physical Fitness, 54, 581-587.

3. Berthoin, S., Dupont, G., Mary, P., \& Gerbeaux, M. (2001). Predicting sprint kinematic parameters from anaerobic field tests in physical education students. The Journal of Strength \& Conditioning Research, 15(1), 75-80.

4. Bosco, C. (1994). La Valoracio'n de la Fuerza con el Test de Bosco. Barcelona: Editorial Paidotribo.

5. Gambetta, V. (1986). Practical considerations for utilizing plyometrics-Roundtable. NSCA Journal, $14-22$.

6. Гредељ, М., Метикош, Д., Хошек, А., \& Момировић, К. (1975). Модел хијерархијске структуре моторичких способности. Резултати добивени примјеном једног неокласичног поступка за процјену латентних димензија. Кинезиолоїиja, 5(1-2), 7-82.

7. Delextrat, A., \& Cohen, D. (2008). Physiological testing of basketball players: toward a standard evaluation of anaerobic fitness. The Journal of Strength \& Conditioning Research, 22(4), 10661072.

8. Zatsiorsky, V., \& Kraemer, W. (2009). Nauka i praksa $u$ treningu snage (Science and practice in strength training). Beograd: Data status. између кошаркаша различитог узраста. Применом t-теста, добијени су резултати који показују да постоје статистички значајне разлике између кошаркаша различитог узраста у свим посматраним варијаблама у корист кошаркаша узраста 14 година. Добијени резултати дају значајну информацију тренерима приликом селекције кошаркаша, могу помоћи у правилном плану и програму рада са кошаркашима различитог узраста и указати на даља истраживања у пољу експлозивне снаге кошаркаша различитог узраста.

9. Zhang, X. (2013). Research of Jumping Ability and Explosive Power Based on PlyometricTraining. (Istraživanja skakačkih sposobnosti i eksplozivne snage bazirana na pliometrijskom treningu). Lecture Notes in Electrical Engineering, 206, 427-433.

10. Ziv, G., \& Lidor, R. (2010). Vertical jump in female and male basketball players-review of observational and experimental studies. Journal of Science and Medicine in Sport, 13(3), 332-339.

11. Khlifa, R., Aouadi, R., Hermassi, S., Chelly, M. S., Jlid, M.C., Hbacha, H., \& Castagna, C. (2010). Effects of a plyometric training program with and without added load on jumping ability in basketball players. The Journal of Strength \& Conditioning Research, 24(11), 2955-2961.

12. Kocić, M., Berić, D., Radovanović, D., \& Simović, S. (2012). Differences in mobility, situational, motor and functional abilities of basketball players at different levels of competition. Facta universitatis, Series: Physical Education and Sport, 10(1), 23-32.

13. Köklü, Y., Alemdaroğlu U., Ünver Koçak, F., Erol A.E., \& Findikoğlu, G. (2011). Comparison of Chosen Physical Fitness Characteristics of Turkish Professional Basketball Players by Division and Playing Position. Journal of Human Kinetics (Section III- Sports Training), 30, 99-106.

14. Kolb, J.J. (2003). Get Fit Now for High School Basketball: The Complete Guide for Ultimate Performance. Hatherleigh Press.

15. Курелић, Н., Момировић, К., Стојановић, М., Штрум, Ј., Радојевић, Ђ. \& Вискић-Шталец,

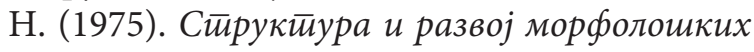
и мотиоричких gимензија омлаgине. Београд: 
Институт за научна истраживања Факултета за физичко васпитање у Београду.

16. Latin, R.W., Berg, K., \& Baechle, T. (1994). Physical and Performance Characteristics of NCAA Division I Male Basketball players. The Journal of Strength \& Conditioning Research, 8(4), 214-218.

17. Maffiuletti, N.A., Cometti, G., Amiridis, I.G., Martin, A., Pousson, M., \& Chatard, J.C. (2000). The Effects of Electromyo-stimulation Training and Basketball Practice on Muscle Strength and Jumping Ability. International Journal of Sports Medicine, 21(6), 437-443.

18. Matavulj, D., Kukolj, M., Ugarkovic, D., Tihanyi, J., \& Jaric, S. (2001). Effects of plyometric training on jumping performance in junior basketball players. Journal of Sports Medicine and Physical Fitness, 41(2), 159-164.

19. McBride, J.M., Triplett-McBride, T., Davie, A., \& Newton, R.U. (2002). The effect of heavy-vs. lightload jump squats on the development of strength, power, and speed. The Journal of Strength \& Conditioning Research, 16(1), 75-82.

20. McInnes, S.E., Carlson, J.S., Jones, C.J., \& McKenna, M.J. (1995). The physiological load imposed on basketball players during competition. Journal of Sports Sciences, 13(5), 387-397.

21. Meyer, R.A., Brown, T.R., Krilowicz, B.L., \& Kushmerick, M.J. (1986). Phosphagen and intracellular $\mathrm{pH}$ changes during contraction of creatine-depleted rat muscle. American Journal of Physiology-Cell Physiology, 250(2), C264-C274.

22. Moreno, E. (1994). Defining and developing quickness in basketball, Part I. Strength Condition, 16, 53-54.

23. Narazaki, K., Berg, K., Stergiou, N., \& Chen, B. (2009). Physiological demands of competitive basketball. Scandinavian Journal of Medicine \& Science in Sports, 19(3), 425-432.

24. Ostojić, S.M., Stojanović, M., \& Ahmetović, Z. (2010). Vertical jump as a tool in assessment of muscular power and anaerobic performance. Medicinski pregled, 63(5-6), 371-375.

25. Pauletto, B. (1994). Strength training for basketball. Human Kinetics.

26. Pavlović, D. (2007). Specifičnosti razvoja snage i brzine kod mlađih košarkaša. Zbornik radova sa Međunarodne naučne konferencije Kondiciona priprema sportaša (str.160-163). Zagreb: Kineziološki fakultet sveučilišta u Zagrebu i Udruga kondicijskih trenera Hrvatske.

27. Santos, E.J., \& Janeira, M.A. (2011). The effects of plyometric training followed by detraining and reduced training periods on explosive strength in adolescent male basketball players. The Journal of Strength \& Conditioning Research, 25(2), 441-452.

28. Santos, E.J., \& Janeira, M.A. (2012). The effects of resistance training on explosive strength indicators in adolescent basketball players. The Journal of Strength \& Conditioning Research, 26(10), 2641-2647.

29. Simenz, C.J., Dugan, C.A., \& Ebben, W.P. (2005). Strength and conditioning practices of National Basketball Association strength and conditioning coaches. The Journal of Strength \& Conditioning Research, 19(3), 495-504.

30. Stojanovic, M., Ostojic, S., Calleja-González, J., Milosevic, Z., \& Mikic, M. (2012). Correlation between explosive strenght, aerobic power and repeated sprint ability in elite basketball players. Journal of Sports Medicine and Physical Fitness, 52(4), 375-381.

31. Hoare, D.G. (2000). Predicting success in junior elite basketball players-the contribution of anthropometic and physiological attributes. Journal of Science and Medicine in Sport, 3(4), 391-405.

32. Hoffman, J.R., Tenenbaum, G., Maresh, C.M., \& Kraemer, W.J. (1996). Relationship Between Athletic Performance Tests and Playing Time in Elite College Basketball Players. The Journal of Strength \& Conditioning Research, 10(2), 67-71.

33. Carlock, J.M., Smith, S.L., Hartman, M.J., Morris, R.T., Ciroslan, D.A., Pierce, K.C., \& Stone, M.H. (2004). The relationship between vertical jump power estimates and weightlifting ability: a fieldtest approach. The Journal of Strength \& Conditioning Research, 18(3), 534-539.

34. Casartelli, N., Müller, R., \& Maffiuletti, N. A. (2010). Validity and reliability of the myotest accelerometric system for the assessment of vertical jump height. The Journal of Strength \& Conditioning Research, 24(11), 3186-3193.

35. Castagna, C., Ganzetti, M., Ditroilo, M., Giovannelli, M., Rocchetti, A., \& Manzi, V. (2013). Concurrent validity of vertical jump performance 
assessment systems. The Journal of Strength \& Conditioning Research, 27(3), 761-768.

36. Chu, D. A., Faigenbaum, A. D., \& Falkel, J. E. (2006). Progressive plyometrics for kids. Monterey, CA: Healthy Learning.

37. Cohen, J. (1988). Statistical Power Analysis for the Behavioral Sciences. New Jersey: Lawrence Erlbaum Associates.
38. Čoh, M. (2004). Metodika i dijagnostika razvoja skočnosti u kondicijskoj pripremi sportaša. Zbornik radova sa Međunarodne naučne konferencije Kondiciona priprema sportaša (str. 104-118). Zagreb: Kineziološki fakultet sveučilišta u Zagrebu i Udruga kondicijskih trenera Hrvatske.

\section{UNTERSCHIEDE IN DER EXPLOSIVEN KRAFT BEI BASKETBALLSPIELERN UNTERSCHIEDLICHEN ALTERS}

\section{Zusammenfassung}

Die Untersuchung wurde an einem Muster von 34 Basketballspielern des Basketballclubs „Ras“ aus Novi Pazar durchgeführt. Davon waren 17 Spieler im Alter von 11 Jahren und 17 Spieler im Alter von 14 Jahren (+/- 0.5 Jahre). Ziel der Untersuchung war es, die Unterschiede zwischen der explosiven Kraft bei Basketballspielern unterschiedlichen Alters festzustellen. Für die Einschätzung der explosiven Kraft wurden sechs Tests angewendet: Weitsprung aus dem Stand, Dreisprung aus dem Stand, Medizinballwurf aus liegender Position, Medizinballwurf aus Sitzposition mit gespreizten Beinen, 20 Meter-Sprint aus niedrigem Start, 30 Meter-Sprint aus hohem Start. Für die Festlegung der Bedeutung der Unterschiede der Mittelwerte der beiden Gruppen wurde der t-test angewendet. Die statistische Bedeutung der Unterschiede wurde auf der Ebene $(\mathrm{p}<0.05)$ analysiert. Die Ergebnisse weisen darauf hin, dass statistisch bedeutende Unterschiede zwischen Baskettballspielern unterschiedlichen Alters in allen betrachteten Variablen zu Gunsten der Basketballspieler im Alter von 14 Jahren vorhanden sind.

Schlüsselwörter: BASKETBALLSPIELER / SPRÜNGE / WÜRFE / SPRINT

Примљен: 13.10.2016.

Прихваћен: 10.04.2017. 